\title{
A Case of Merkel Cell Carcinoma on the Finger
}

\author{
Jong-Kil Seo, Hyung-Jin Park, Min Kyung Shin, Ki-Heon Jeong \\ Department of Dermatology, School of Medicine, Kyung Hee University, Seoul, Korea
}

\begin{abstract}
Dear Editor:
Merkel cell carcinoma (MCC) is a rare neuroendocrine cancer of the skin. The annual incidence of MCC is 0.6 per 100,000 persons in the United States, though the rate is increasing ${ }^{1}$. However, in Asians, there have been fewer case reports of this cancer, and the incidence of MCC is estimated to be 25 times lower than that of whites ${ }^{2}$. It is a highly aggressive primary skin cancer and the leading cause of death in non-melanoma skin cancer ${ }^{3}$. Usual presentation of primary MCC is a solitary violet or blue dome-shaped rapidly growing nodule with non-tender intra-cutaneous swelling. The common locations are head and neck $(50 \%)$, extremities $(40 \%)$, and trunk $(10 \%)^{4}$. Finger involvement has been rarely reported.
\end{abstract}

An 87-year-old female presented with an asymptomatic mass on the finger. Metastatic cancer was suspected, and she was referred to our department as a result of histopathologic examination performed at another hospitals. Physical examination revealed a solitary $1.5 \times 1 \mathrm{~cm}$ sized erythematous nodule on the dorsal surface of the left 4 th finger (Fig. 1). She had diabetes, hypertension, and Alzheimer's disease. We performed skin biopsy and immunohistochemistry on the lesion. The histopathological evaluation demonstrated intradermal coalescing sheets consisting of small blue cells with many atypical mitotic features. Immunohistochemical findings were positive for CK-20 and negative for anti-thyroid transcription factor-1

Received March 29, 2018, Revised June 22, 2018, Accepted for publication July 4, 2018

Corresponding author: Ki-Heon Jeong, Department of Dermatology, School of Medicine, Kyung Hee University, 23 Kyungheedae-ro, Dongdaemun-gu, Seoul 02447, Korea. Tel: 82-2-958-8510, Fax: 82-2-969-6538, E-mail: mdfamily@naver.com

ORCID: https://orcid.org/0000-0001-6908-0932

This is an Open Access article distributed under the terms of the Creative Commons Attribution Non-Commercial License (http://creativecommons. org/licenses/by-nc/4.0) which permits unrestricted non-commercial use, distribution, and reproduction in any medium, provided the original work is properly cited.

Copyright (c) The Korean Dermatological Association and The Korean Society for Investigative Dermatology and S-100 (Fig. 2). Because there were no other skin lesions or evidence of metastasis on positron emission tomography/computed tomography, the patient was finally diagnosed with primary MCC. We transferred the patient to the department of orthopedics. The tumour was excised widely with a $10 \mathrm{~mm}$ margin of surrounding tissue. The axillar sentinel lymph node biopsy result was negative. After the surgery, adjuvant radiotherapy was performed. The patient was followed up one year after the surgery without recurrence.

The pathogenesis and risk factors of MCC are not fully understood. But, the known risk factors for MCC are sun exposure, immunosuppression, and Merkel cell polyomavirus infection ${ }^{1}$. Of all cases of MCC, $85 \%$ appear in sun exposed sites, so ultraviolet exposure seems to be a significant etiological factor ${ }^{4}$. The occurrence of MCC at the hands and fingers is likely to occur due to exposure to sunlight. A case report showed the relation of ionizing radiation exposure with the development of MCC in an 80year-old surgeon who had frequently performed radiography using the naked hand ${ }^{5}$. Although The hand and finger may be relatively easy to expose with sun-exposure and naked radiation, MCC on these sites has been rarely

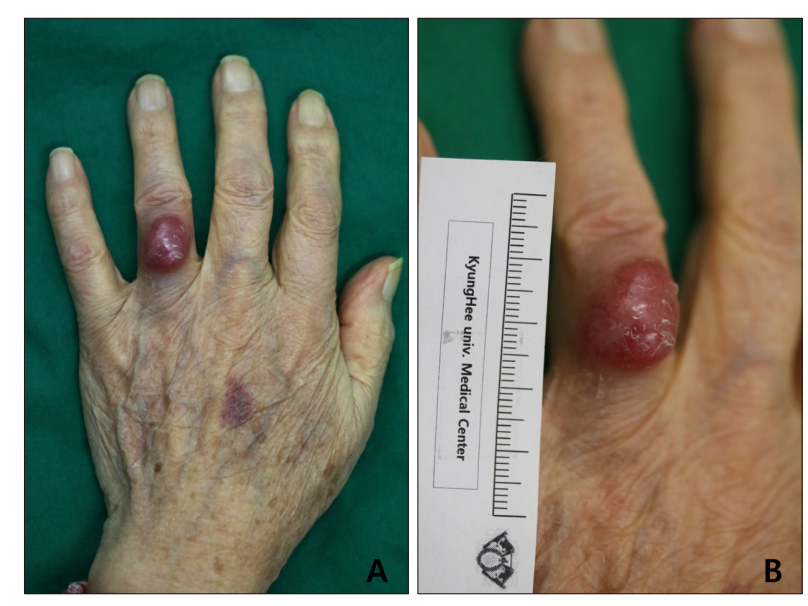

Fig. 1. (A, B) Solitary $1.5 \times 1 \mathrm{~cm}$ sized erythematous nodule on the dorsal surface of the left 4 th finger. 

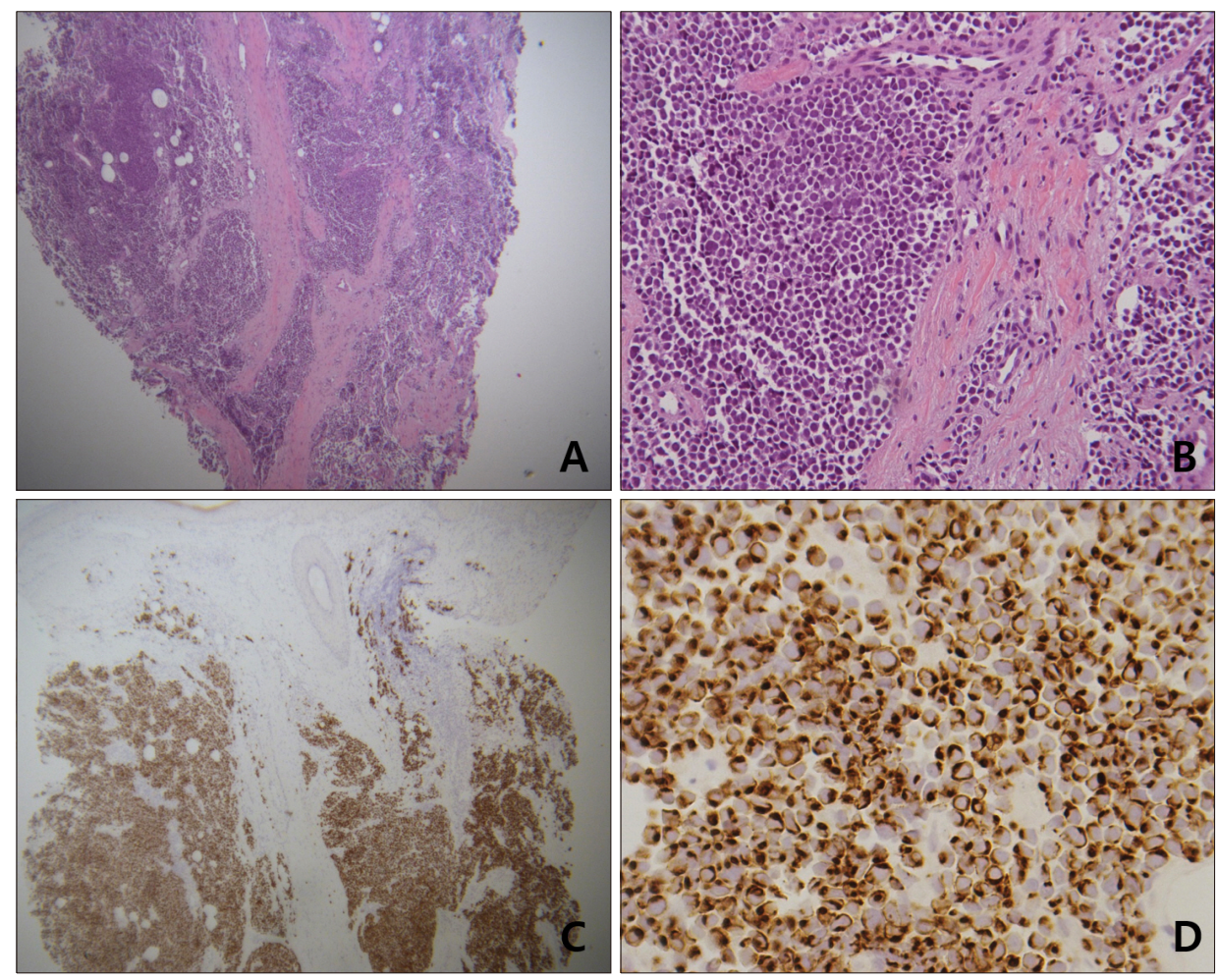

Fig. 2. Histologic findings. (A) IIIdefined tumor masses consisted of blue cells arranged in large sheets infiltrating entire dermis $(\mathrm{H} \& \mathrm{E}, \times 40)$. (B) Uniform, atypical, small blue cells with hyperchromatic nuclei and scanty cytoplasm $(\mathrm{H} \& \mathrm{E}, \times 200)$. (C) Immunohistochemical (IHC) staining of tumor mass in the dermis showing positive for CK-20 (IHC stain with CK-20 antibody, $\times 40$ ). (D) CK-20 was stained positive in tumor cells (IHC stain with CK-20 antibody, $\times 400$ ). reported $^{4,5}$. Because of frequent sun-exposure and a high density of Merkel cells on the hand, however, the possibility of the occurrence of MCC would not be negligible. Dermatologists should include the possibility of MCC when encountering painless firm erythematous nodules, especially in sun-exposed areas. Although rarely reported, considering the aggressive aspect of this cancer, MCC in the hands or fingers should be considered. If diagnosis is challenging, immunohistochemical staining is useful in diagnosis of MCC. We received the patient's consent form about publishing all photographic materials.

\section{ACKNOWLEDGMENT}

We received the patient's consent form about publishing all photographic materials.

\section{CONFLICTS OF INTEREST}

The authors have nothing to disclose.

\section{ORCID}

Jong-Kil Seo, https://orcid.org/0000-0001-8822-6466

Hyung-Jin Park, https://orcid.org/0000-0002-5952-9158

Min Kyung Shin, https://orcid.org/0000-0001-9834-7931

Ki-Heon Jeong, https://orcid.org/0000-0001-6908-0932

\section{REFERENCES}

1. Hughes MP, Hardee ME, Cornelius LA, Hutchins LF, Becker JC, Gao L. Merkel cell carcinoma: epidemiology, target, and therapy. Curr Dermatol Rep 2014;3:46-53.

2. Coggshall K, Tello TL, North JP, Yu SS. Merkel cell carcinoma: an update and review: pathogenesis, diagnosis, and staging. J Am Acad Dermatol 2018;78:433-442.

3. Chun SM, Yun SJ, Lee SC, Won YH, Lee JB. Merkel cell polyomavirus is frequently detected in Korean patients with merkel cell carcinoma. Ann Dermatol 2013;25:203-207.

4. Spalvieri C, Brunelli F, Bachmeyer CC. Merkel cell tumour of the finger. Scand J Plast Reconstr Surg Hand Surg 2007; 41:149-151.

5. Ansai S, Noro S, Ogita A, Fukumoto H, Katano H, Kawana S. Case of Merkel cell carcinoma with squamous cell carcinoma possibly arising in chronic radiodermatitis of the hand. J Dermatol 2015;42:207-209. 